\title{
ADOPTION PROCESSES FOR EDM, EDI AND BIM TECHNOLOGIES IN THE CONSTRUCTION INDUSTRY
}

\author{
Olle SAMUELSON ${ }^{\mathrm{a}}$, Bo-Christer BJÖRK ${ }^{\mathrm{b}}$ \\ ${ }^{a} I Q S$ AB, Drottninggatan 26, 11151 Stockholm, Sweden \\ ${ }^{b}$ Hanken School of Economics, Perhogatan 6, Helsinki, Finland \\ Received 26 Sep 2011; accepted 27 Mar 2012
}

\begin{abstract}
Three strategically important uses of IT in the construction industry are management of project documents on webservers (EDM), electronic handling of orders and invoices between companies (EDI) and use of 3D models including non-geometrical attributes for integrated design and construction (BIM). The purpose of this work is to study factors that affect the decisions to implement these techniques as well as the actual adoption process. In a longitudinal survey study in the Swedish Construction Industry, the extent of use of these techniques was measured in 1998, 2000 and 2007. This paper presents a follow-up to the quantitative studies, where semi-structured interviews have been used, in a qualitative approach. The theoretical basis for the studies was informed by frameworks from IT-adoption theory. The results showed that decisions to implement these technologies are made on three different levels: individual level, company organizational level, and project organizational level. Different patterns in adoption can be explained by where decisions are mainly taken. EDM is driven from the project level, EDI mainly from the company level, and BIM is driven by individuals. The study points out that decision for implementing BIM should be taken on a higher strategic level in order to deliver intended benefits.
\end{abstract}

Keywords: IT, innovations, construction, adoption, implementation.

Reference to this paper should be made as follows: Samuelson, O.; Björk, B.-C. 2013. Adoption processes for EDM, EDI and BIM technologies in the construction industry, Journal of Civil Engineering and Management 19(Supplement 1): S172-S187. http://dx.doi.org/10.3846/13923730.2013.801888

\section{Introduction}

\section{IT-adoption in construction}

In the same way as in other industries and in society in general IT has had profound effects on the way the construction industry conducts its business. Already in the 1970s computers facilitated the technical calculations needed particularly in structural design. In the 1980s the PC arrived and made the production of written documents as well as previously tedious tasks like cost calculation and budgeting much easier. In parallel Computer-aided Design (CAD), first using dedicated workstations and later also on PCs, made the production of drawings much easier. The 1990s saw the advent of the Internet, which has facilitated the access to documents in projects, electronic ordering, etc. The proliferation of mobile phones has also been of tremendous help to this industry where much of the work is done on site. The first decade of the $21^{\text {st }}$ century has seen few new basic tools emerge, but rather the maturing use of many of the technologies mentioned above, for example the changes in processes that have started as a result of increased BIM use and ongoing discussions of virtual construction, as well as an everincreasing integration of computers, mobile devices and networks.
This paper focuses on three particular IT innovations: Electronic Document Management (EDM), Electronic Data Interchange (EDI) and Building Information Modelling (BIM). In the following text the acronyms will be used to denote these.

The chosen innovations all build on communication and information exchange between actors in the sector. The information exchange is also characterised by manyto-many relationships, since the actors (companies) tend to cooperate in new constellations which change from project to project (Slaughter 1998). This also means that there is a need for standards for information exchange, for instance concerning methods for document storage in EDM, formats and contents for data fields in EDI or object definitions in BIM. The productivity and quality benefits of a wide-spread implementation of these innovations for the whole sector have also been envisaged as high (Thomas 1999).

The three technologies differ in some essential ways, which is one of the aspects we studied. The differences concern in particular the complexity of the information handled, where the management of document meta-data in EDM must be regarded as the simplest. The standardised messages which are used in EDI are more complex since the degree of standardisation must be so 
specific that all the data needed from the price of a product to the confirmation that it has been delivered and paid for, can be handled, including a number of special cases which might be needed in a step-by-step process. BIM has been described by Eastman et al. (2008) as containing all information about the product and the process throughout the whole life-cycle of a built object. The definitions, hierarchies and relationships which are needed for a stringent management of such information are on a totally different level of complexity compared to the other two areas.

There has been a lot of research in innovations in construction (e.g. Blayse, Manley 2004; Dubois, Gadde 2002; Gann, Salter 2000; Slaughter 2000) and there is also literature to be found regarding IT implementation in the construction sector (e.g. Gambatese, Hallowell 2011; Koskela, Dave 2008; Peansupap, Walker 2005; Stewart et al. 2004). The three focus areas EDM, EDI and BIM have mostly been studied from a technical perspective but some adoption or implementation studies can be found as Björk (2006) regarding EDM; Ramamurthy et al. (1999) for EDI and Kunz, Fischer (2008) handling BIM. There is however a lack of research done that has used existing generic IT adoption theory, in the context of the construction industry.

The purpose of the paper is to increase the understanding of the adoption and implementation processes of IT in the construction and real estate sector, focusing on the three areas EDM, EDI and BIM. The goal is, with the background of the authors' previous studies, and existing innovation theory, to describe factors that influence the decisions to take into use these innovations on different levels, and describe how the actual implementation of them has occurred.

\section{Project based electronic document management -EDM}

The concept EDM (Electronic Document Management) describes electronic document management in general, but here we study only project based EDM, i.e. the documents shared and exchanged between the different partners in construction projects, usually via web based user interfaces.

All the information which is created in projects has traditionally been formalised in documents: drawings, text documents and numerical documents such as lists and tables, and which describe the planned construction project both concerning the product and the process. Earlier these documents have been sent in physical form (paper) to those participants who at any given moment have needed access to the information.

For such documents, new technology has created possibilities both to easily create, via word processing, to multiply, via photocopying and digital files, and to communicate, via email and the web. This has resulted in a strongly increased flow of documents and also other information.

The traditional way to distribute information to all possible users (push) in combination with increased volumes has led to a problem of information overflow. Many tend to send copies to an increasing number of reci- pients "just-in-case". This results in a problem for the recipient in sorting out the important and relevant information. Thorpe and Mead (2001) describe how a change of philosophy from push to pull is one of the benefits of document management systems, where documents instead are stored in virtual storage places with access for those who need it.

Different systems for EDM emerged in the 1990s and the proliferation of the Internet which enabled the communication paths was the key enabling factor (Löwnertz 1998). EDM systems typically treat the documents used in a project as black boxes, and are primarily focused on storing these in a systematic way, usually on one web server with shared access for all participants. The functionality of such systems differs somewhat from system to system and the more sophisticated ones have advanced work flow capabilities, connections to copying firms for traditional paper output, etc. (Sulankivi et al. 2002). A common feature of most systems is that they require agreeing on a structure for the definition of the meta-information about the documents.

Among the advantages of such systems can be mentioned shared access to information, structured ways of searching for documents, version management, the possibility to read and utilise information without access to the software used to create it, etc. In other words the systems create a platform to keep in good order all the document based information which is exchanged in a construction project. This creates a big potential for making the overall process more efficient, since one of the challenges of the construction sector is its information intensive project form with new constellations of partners for each new project.

There have been relatively few earlier studies of the adoption of EDM in the construction industry. O'Brien (2000) highlighted the fact that the users of a system in a project cannot be treated as one uniform group, but rather consist of several groups with different attitudes and skills. The problem with an EDM system is that successful use requires that all of these adopt the system at the same time. Nitithamyong and Skibniewski (2004) identified a number of factors determining success or failure of such systems. Hjelt and Björk (2007) studied the adoption and use of a single system on big and complex construction project, and especially changes in the attitudes of different categories of users after they had started using the system.

\section{Electronic business - EDI}

The concept EDI (Electronic Data Interchange) is sometimes interpreted as business information which is transferred using the standardised EDIFACT format, which is a too narrow definition. Hill and Ferguson (1998) describe EDI as "the movement of business data electronically between or within firms (including their agents or intermediaries) in a structured, computer-processable data format that permits data to be transferred without rekeying from a computer-supported business application in one location to a computer-supported business application in another location". The messages can be exchanged 
in different formats such as Edifact or XML. A necessity for the communication of business data between companies is that the systems understand each other. Hence standards for how such information should be described have been developed, in the same way as for BIM. The development of EDIFACT started towards the end of 1980 s, but has been preceded by other standards in the 1970s (Muehlen et al. 2005). The strong growth and proliferation of the Internet during the 1990s opened up opportunities for developing EDI services using web techniques.

In the building sector EDI has mainly been used for transactions between contractors and the construction materials industry where the biggest exchange of products and the most numerous economic transactions occur. A fully developed EDI-flow requires both investments and a technical platform, which implies that a minimum level of traffic is needed for profitable deployment. For this reason such solutions are often based on long-term agreements between two parties. Research about the adoption of EDI in the construction sector is very scarce (cf: O'Brien, Al-Soufi 1993; Laage-Hellman, Gadde 1996).

\section{Building Information Modelling - BIM}

Ever since designers started using computers instead of drawing boards as an aid in the production of drawings, there have been visions of how the created information could be more extensively used downstream in the process (Eastman et al. 2008). In traditional design drawings, created by hand or using 2-D CAD, buildings are presented as graphical representations. This graphic needs to be interpreted by people. In computer-aided model based design on the other hand, the building elements are created as objects in a data base and properties can be associated with these objects. Hence the information can be interpreted by a computer and communicated between different systems, and also presented to humans in different formats for different purposes. In summary model based information management means:

- Shared access to all information;

- Less risk for redundant work, when each data item is stored only in one place;

- A higher quality of the information and hence also both in the process and the end product;

- Faster information access and lower costs.

The effects of such a method for information handling on the productivity of the construction sector have been estimated as being high, (e.g. Eastman et al. 2008; Azhar et al. 2008; Suermann, Issa 2007). In order to get there a high degree of coordination on a high level is needed since the fragmentation of the construction industry and it principles of procurement rather tend to favour sub optimisation, in which each actor only uses BIM if he can reap direct economic benefits within the confines of his own work. This has led to a discussion and an extension of the concept of BIM (Building Information Model) to include also the changes in work methods and processes needed to take advantage of the improved information mana- gement, i.e. Building Information Modelling. BIM may thus be regarded both as a noun and a verb.

The Industry Foundation Classes (IFC) is a vendor neutral format with the intention of becoming an information structure common to the whole sector, which can be used throughout a building's lifecycle, (e.g. Building Smart 2010). Tarandi (1998) describes the IFC as a conceptual schema, the purpose of which is to serve as a basis for information sharing throughout the life cycle of the project, between disciplines and between technical IT applications. The spread of the IFC in practical applications has, however, not happened with the speed envisaged (Kiviniemi 2006).

In many practical BIM applications today existing programs and file formats are instead used, with bilateral connections between the different systems. The management of IFC files and model servers is a too big hurdle to take and instead the model files that the designers create are used via direct export to other programs where the data is reused. The transfer of information back to the original application is seldom done. The sharing of data back and forth quite soon becomes very difficult if there is no common "language".

BIM or its predecessor building product modelling has been a favourite topic for construction IT researchers for the past 25 years and hundreds of journal and conference papers have been written about the topic (Amor et al. 2002). Most of these have however focused more on the technical structures required for BIM and on reporting prototypes, rather than the adoption process and problems. Authors who have discussed the adoption process include Kiviniemi (2006), Howard and Björk (2008) and Björk and Laakso (2010). There have also been quite a few case studies of BIM pilot projects reported which can contribute to our understanding of the adoption processes (Olofsson et al. 2008).

\section{Results from earlier parts of the study}

This paper presents the results from the latest data collection in a longitudinal study of IT use and development in the Swedish construction and facility sector. The research project (initially called the "IT-barometer") started in 1997 and has been carried out in phases with five data collections during a 12 year period. Chapter 2 presents a brief summary of results from the earlier phases which constitute an important background to the results later presented in the paper.

\subsection{Quantitative studies}

The first part of the study consisted of a broad quantitative study of the use of IT in the Swedish Construction Industry, which was repeated with only minor changes in 1998, 2000 and 2007. The methods and results of the study have been reported in diagrams and tables and these have provided the basis for analysis and conclusions concerning the use of IT in the construction and FM sector (Samuelson 2002, 2008).

The method is described in detail elsewhere (Samuelson 2002) and this is a short summary. The summary is 
included to give an understanding of how the results in Figs 1-3 are measured. The target population is the construction and facility management sector, which has been defined on the basis of the register from Statistics Sweden and includes all workplaces in Sweden in five categories: architects, technical consultants, contractors, property owners and the materials industry. A workplace is defined as each address where a company carries out activities. This approach makes the answers more balanced, since bigger companies with different activities may have difficulties in giving answers for the whole company. The workplaces are also divided into four sizes with respect to the number of employees: 1-9, 10-49, 50-199 and 200-. The selection was made as a stratified free random selection, where stratified stands for the division into the categories and sizes above. A free random selection was then made for each stratum. The selection size, number of answers and response rate for each survey is given in Table 1.

Since the IT-Barometer aimed at describing the situation in this industry as a whole, it is important to consider the size of the companies. The answers have been weighted with respect to number of employees in each workplace, to make sure that every answer represents its part of the industry. This method has been used each time and is well described in Samuelson (2002).

The development in the use of the three focus areas is summarized below in a figure for each area. The results of the focus areas are presented only for 2000 and 2007 since the questions were not asked in the same way in 1998. However, there are other areas in the surveys that have been followed over the three measurement points (Samuelson 2002, 2008).

Table 1. Response rate for the surveys in the earlier parts of the study. The survey was conducted via paper mail in 1998 and 2000 and using a web questionnaire in 2007, which explains the lower response rate in the last phase

\begin{tabular}{l|c|c|c}
\hline & 1998 & 2000 & 2007 \\
\hline Selection size & $2723^{1}$ & 1316 & 1385 \\
\hline Number of answers & 636 & 641 & 180 \\
\hline Response rate & $\mathbf{2 3 \%}$ & $\mathbf{4 9 \%}$ & $\mathbf{1 3 \%}$ \\
\hline
\end{tabular}
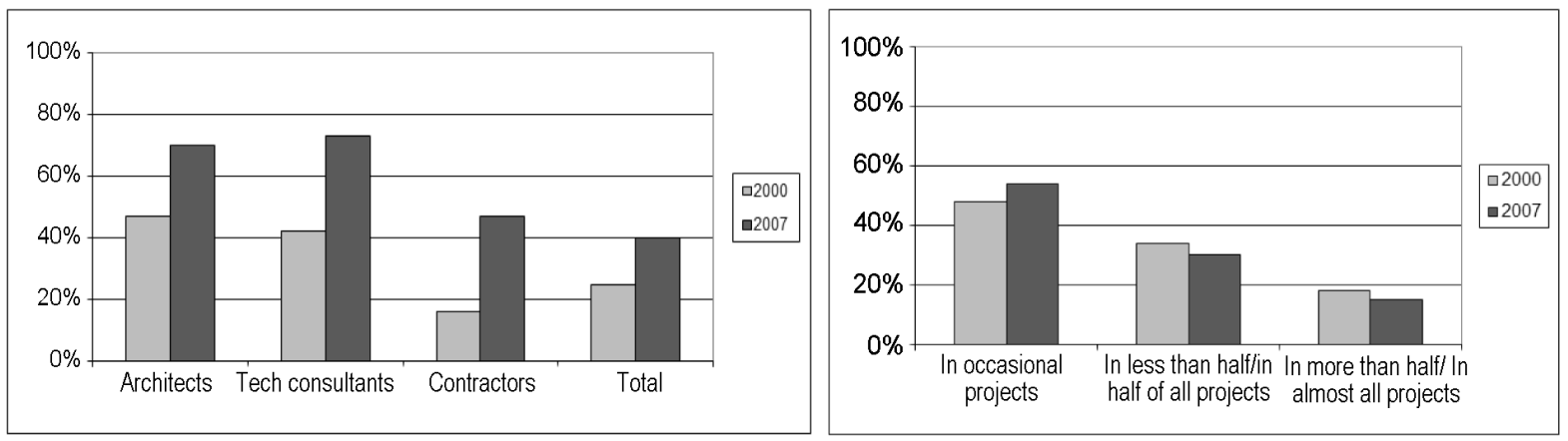

Fig. 1. Proportion of employees in workplaces, where EDM has been used (left), frequency of use (right)
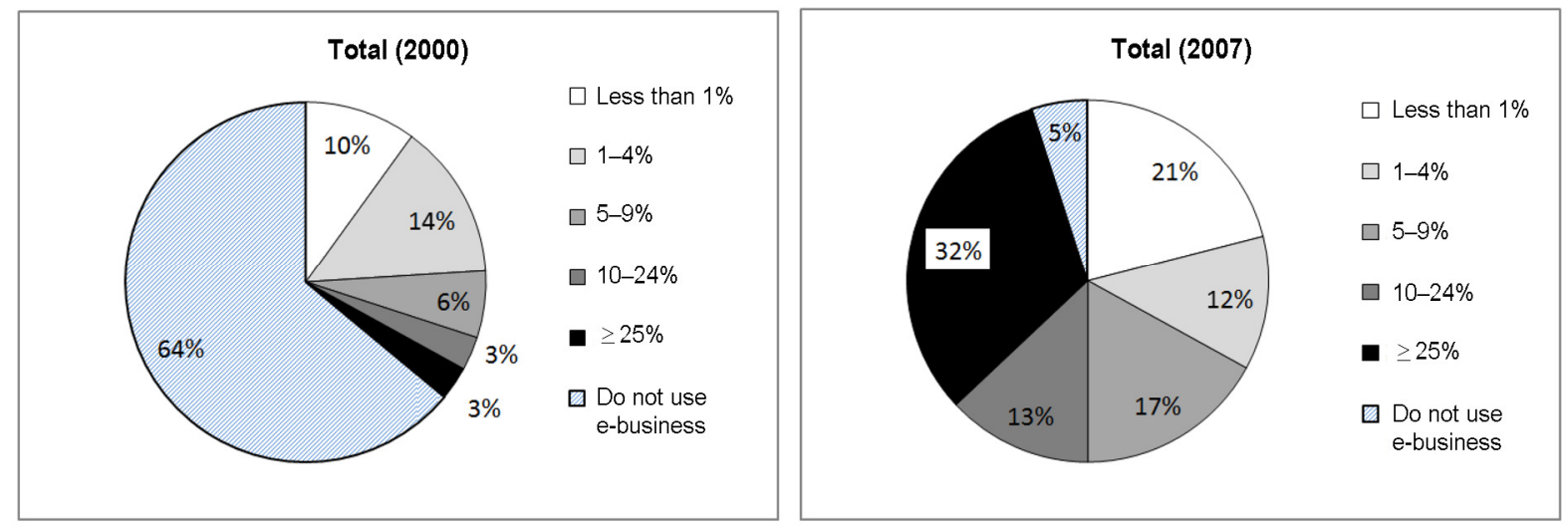

Fig. 2. Proportion of turnover (2000, left) and purchase (2007, right), in workplaces where some e-business have been used

\footnotetext{
${ }^{1}$ A bigger selection was made to get results for combinations of strata, for example Architects with 10-49 employees. For the later surveys, the result where presented either by categories or by size.
} 

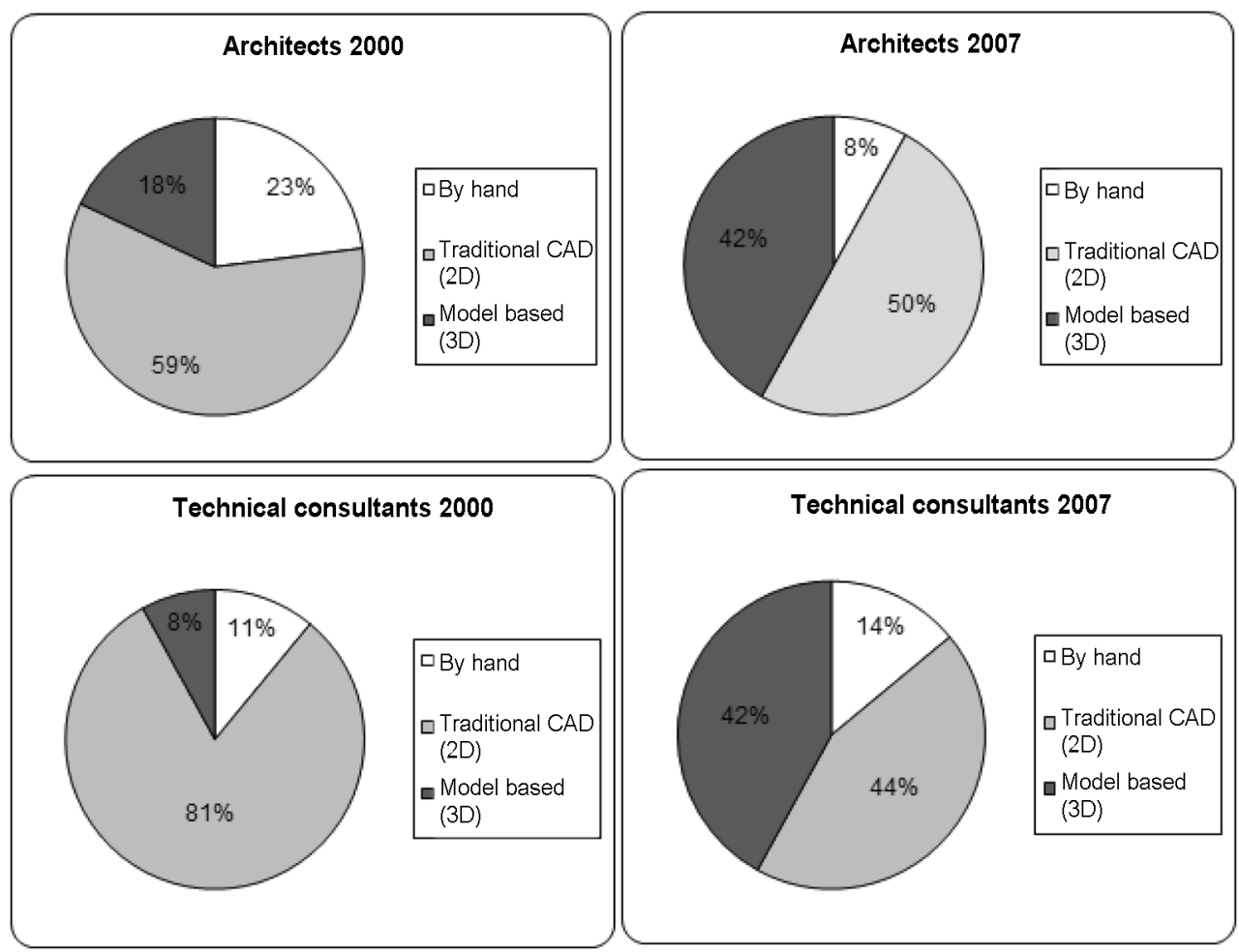

Fig. 3. Proportion of total time spent on design, where different tools have been used, 2000 and 2007

The proportion of users of EDM has increased significantly in all categories of companies during the measurement period. The proportion of those who use EDM has increased from $22 \%$ to $40 \%$ in total, as illustrated in Fig. 1. Interviews in the second part of this study, which is described in chapter 3, have shown that EDM systems are used in all projects where the benefit is estimated to become higher than the effort, which in practice means in all bigger projects.

The biggest changes occurred in the area of ebusiness, where the proportion of those who do not use ebusiness at all, has decreased from $64 \%$ to $5 \%$, see Fig. 2 . The type of use has in the study been divided into four categories: Web shops, Market places, Extranets/Web EDI and EDI (Samuelson 2008). The survey shows that the greatest use is in the simplest form, through web shops (Samuelson 2008), but that almost the entire sector has begun using e-business at least in some form, see Fig. 2.

Fig. 3 shows which types of software are used by designers to produce documents for construction projects and how the use has changed during the period. There has been a huge increase in the use of software that can handle 3D and object based models. Architects were earlier with this use than the technical consultants, with $18 \%$ in 2000 compared to $8 \%$. But in 2007 the proportion was quite similar in the two categories, with $50 \%$ for architects and $44 \%$ for the technical consultants. The proportion of drawing by hand, however, was much higher among architects in 2000 , but has now fallen to the equivalent level of technical consultants.

The extent of use within the three focus areas EDM, EDI and BIM in the quantitative study can be summari- zed as follows, with reference to the description above and to previous publications (Samuelson 2002, 2008):

- The use within all three areas has increased markedly during the period, especially between 2000 and 2007;

- The use of project-based EDM has levelled out. EDM-systems are used in projects where the benefits are bigger than the effort needed, which in practice means almost all bigger projects;

- The use of E-business in some form has increased significantly in the sector. Part of the use is however concentrated to simpler forms of E-business, for instance the handling of invoices or purchases from web shops. Full EDI is primarily used among contractors or in the materials industry;

- The degree of use of BIM has increased. The degree of use is highest among designers but has also started among other actors. The use is still not high compared to EDM and EDI.

\subsection{Qualitative study}

The second part of the study consisted of two qualitative studies carried out in 2003 and 2009. In order to gain a deeper understanding of the obtained results, both studies were made with companies that had answered the IT-barometer survey. The objectives of the two case studies were partly different. In the first study, carried out 2003 , the objective was to understand IT use and adoption in general, mostly based on the results from the surveys. The study, during which 16 persons in 12 companies were interviewed, was carried out without reference to any existing theory about the adoption and diffusion of innovation. As a result a model of the key factors affect- 
ing IT implementation was formulated (Fig. 4) and this influenced the set-up of the second study.

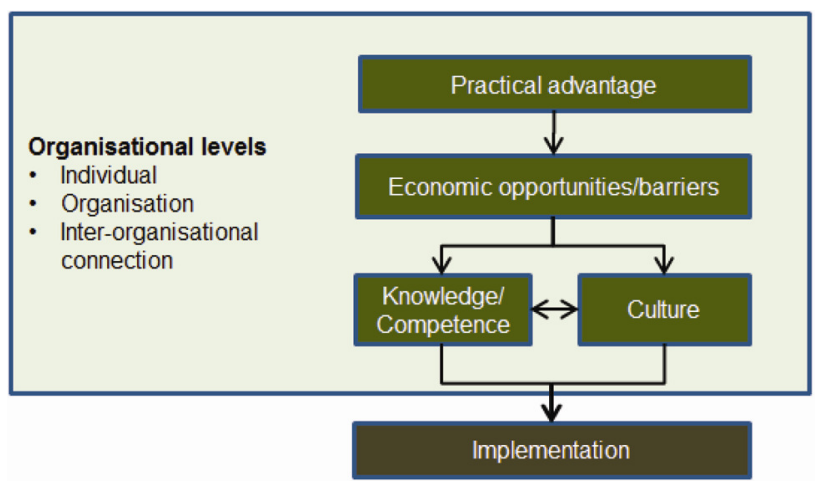

Fig. 4. Approach to factors affecting IT adoption and their relations (from the first case study)

The approach describes how four factors have to interact to lead to an implementation. It also describes that the factors can operate on different organisational levels. The different complexity of implementation on these levels was one of the research topics. The main conclusion drawn from the study was firstly that there are factors that influence the decision (the classification of factors in Fig. 4 is one of several possible), secondly that these factors operate on different levels and thirdly that some kind of process must take place to implement an IT innovation in an organisation. This result was used in the second case study to find models to investigate the adoption and implementation processes further. The work is further described in Samuelson (2010).

\section{Research method}

The second case study, carried out in 2009, constitutes the main focus of this paper. The aim of the second study was to gain an understanding of the three focus areas EDM, EDI and BIM, and here the basis included general IT adoption theory and the theoretical framework from section 2.2 above, as well as the survey responses. In the following, this article focuses on the results of this last data collection. The earlier phases have here only been briefly described to provide a context for the more detailed treatment of the results concerning the three focus areas.

In the second interview study the focus was on the decision and implementation processes for the three focus areas EDM, EDI and BIM. A criterion for inclusion in the study was consequently that the company in question had reported implementation within at least one of the focus areas. The choice of companies was made based on the responses to the 2007 survey and the aim was to include companies from all five categories described in section 2 . Of the companies who fulfilled the requirements, eleven companies were chosen in total, with one interview per company, see Table 2 below. It was also valuable to include companies, which were not implementing all three technologies, so that also the arguments of non-adopters could be studied. The "Yes" and "No" in Table 2 specifies if the company has implemented the technology in question or not. The focus area for each interview is indicated with bold text and grey background.

The process for the case study was divided into three parts: Preparation, Performance and AnalysisSynthesis. The preparation phase included problem definition, scope, choice of interview form and scheduling.

Table 2. Distribution of respondents in the second interview study

\begin{tabular}{|c|c|c|c|c|c|}
\hline Category & $\begin{array}{l}\text { Number of employees } \\
\text { (company group) }\end{array}$ & $\begin{array}{l}\text { The respondent's roll in } \\
\text { the company }\end{array}$ & BIM & EDM & EDI \\
\hline Architect 1 & $20-199$ & BIM Program coordinator & Yes & No & No \\
\hline Architect 2 & $\geq 200$ & IT manager & No & Yes & No \\
\hline Technical consultant 1 & $\geq 200$ & $\begin{array}{l}\text { Regional Development manager, } \\
\text { project Manager BIM }\end{array}$ & Yes & Yes & No \\
\hline Technical consultant 2 & $\geq 200$ & $\begin{array}{l}\text { Vice IT manager, responsible of CAD } \\
\text { development }\end{array}$ & Yes & Yes & No \\
\hline Property manager 1 & $\geq 200$ & $\begin{array}{l}\text { Vice president, responsible of project- } \\
\text { and property development }\end{array}$ & No & Yes & No \\
\hline Property manager. 2 & $20-199$ & IT Project manager & No & Yes & Yes \\
\hline Contractor 1 & $\geq 200$ & Project manager & Yes & Yes & Yes \\
\hline Contractor 2 & $\geq 200$ & Logistics manager & No & Yes & Yes \\
\hline Contractor 3 & $\geq 200$ & Project manager BIM & Yes & & \\
\hline $\begin{array}{l}\text { Materials Manufacturer/ } \\
\text { supplier } 1\end{array}$ & 20-199 & Head of design department & Yes & Yes & No \\
\hline $\begin{array}{l}\text { Materials Manufacturer/ } \\
\text { supplier } 2\end{array}$ & $\geq 200$ & Logistics manager & No & Yes & Yes \\
\hline
\end{tabular}


Semi-structured interviews were chosen as the interview form as it allows a wider discussion, together with a structured approach, which is needed to hold together the interviews around the defined areas and the selected theoretical frameworks. An interview plan was developed based on the three focus areas and the groups of factors described in the UTAUT model in Section 4.

In the performance phase the interviews were carried out, covering $1-1.5 \mathrm{~h}$ per interview. The interview plan consisted of two main parts in which open questions were asked, partly regarding the factors that influence the decision, partly regarding the implementation process and which parts of the process the company had reached for each focus area. The interviews were documented by recording the whole interview and by complementing notes. The phase ended with transcription of the interviews where some comments were submitted, which could be relevant to the analysis.

The final phase Analysis-Synthesis consisted of data reduction, where the data were sorted out and categorized; Pattern matching (Yin 2009) where data were matched towards the selected theoretical framework; and finally the formulation of conclusions and critical review of these. In practice, the analyses consisted of interpreting the answers and statements, in their context, in the interview material; and then break out and encode them in a table, based on the concept in the theoretical frameworks. The synthesis has then been performed by studying the coded data, finding the patterns which can be interpreted and by summarizing the patterns in a table (Table 3 ).

\section{Theory}

Most of the research on IT in Construction, has dealt with different aspects of new ways of using IT to improve parts of the construction process or the process as a whole. Important topics covered have included technical aspects as well as standardisation, organizational and process changes and their effects. There have however been few studies of the mechanisms that affect how these innovations are implemented and spread in the construction sector. There is a lack of research that has used existing theories in diffusion of innovations and IT adoption to study IT innovations in construction. Since theories and models about diffusion and implementation of IT are central to this study, the models that have been used are described and discussed briefly in this chapter.

The intended contribution of this paper is to use general IT adoption theory in the IT construction context to explain, and increase the understanding of, how different types of IT innovations can be implemented in the sector. However, there is no existing model in innovation theory that can explain all the aspects of the topic, including the different levels of implementation that will be discussed further in the paper. Instead, a number of existing models are combined with the purpose to explain the whole situation.

According to Cooper and Zmud (1990) the research in IT adoption can be divided in three categories: Factors research (static factors leading to successful implementation); Process research (dynamic factors leading to su- ccessful implementation) and Political research (differences in interests between the involved stakeholders). These three categories will be discussed and used in the theoretical framework.

\subsection{Levels for decision - political research}

To decide to take into use and apply an innovation is made by individuals. The individuals who make the decisions can, however, act on different levels and with differing levels of influence over other individuals and systems. In this research these levels have been split into three groups:

- Individuals;

- Organizations;

- Inter-organizational systems.

This classification emerged during and as a result of the first interview study. The individual level refers to the lowest level, where individuals in their professional roles, decide to use or not use an IT innovation, primarily for their own benefit. The organizational level typically concerns a company, but can be another form of hierarchical organization with a clear decision procedure, such as a project. The highest level is called inter-organizational system, i.e. a network of several organizations that need to interact, but without a clear decision procedure. One example is provided by different types of industry collaboration, designed to find common approaches for common benefits. Another example is the supply chain in an industry, i.e. dependences between multiple companies in a chain of business. A construction project can be said to belong also to this category because it consists of individuals from different companies with different business processes, IT platforms and cultures. The project is thus both an organization per se, but also influenced by the inter-organizational system that the individual companies belongs to.

The three groups describe the social systems where the innovation is spread and where decisions can be made by an individual or several individuals about the adoption of a particular innovation within the system in question.

Rogers (2003) suggests that there are three types of innovation decisions: Voluntary decisions, where the individual himself decides to implement or not, Collective decisions which are formed by some sort of consensus within a given social system and where all members of the system are expected to follow the decision, and Authority decisions, where somebody is in a position to make a decision which several others belonging to a system have to obey. These are closely related to the three levels discussed above and can usually be found in the combinations: individuals - voluntary decisions, organizations - authority decisions and inter-organizational systems - collective decision. This is, however, a strong simplification of reality and there are several variations where aspects of voluntary choices, authority and consensus can be found.

The different variants that can occur in an organization, where both the organization and the individuals in the organization have to make a decision, is by Gallivan (2001) described in the four field model shown in Fig. 5. It describes four possible outcomes, depending on if the organization and the employees adopt the innovation. 
Table 3. The impact of different variables on the adoption and implementation of EDM, EDI and BIM

\begin{tabular}{|c|c|c|c|c|c|c|c|c|}
\hline & \multicolumn{2}{|c|}{$\begin{array}{l}\text { Performance } \\
\text { Expectancy }\end{array}$} & \multicolumn{2}{|c|}{ Effort Expectancy } & \multicolumn{2}{|c|}{$\begin{array}{l}\text { Facilitating } \\
\text { Conditions }\end{array}$} & \multicolumn{2}{|c|}{ Social Influence } \\
\hline \multirow[t]{8}{*}{ EDM } & \multicolumn{2}{|c|}{$\begin{array}{l}\text { Quality assurance of informa- } \\
\text { tion. }\end{array}$} & \multicolumn{2}{|c|}{$\begin{array}{l}\text { Double handling, } \\
\text { internal and external. }\end{array}$} & \multicolumn{2}{|c|}{$\begin{array}{l}\text { Technical infrastructure - } \\
\text { supporting. }\end{array}$} & \multicolumn{2}{|c|}{$\begin{array}{l}\text { Individual aversion - } \\
\text { inhibiting. }\end{array}$} \\
\hline & Ind. + & Org. + & Ind. - & Org. N/A & Ind. + & Org. + & Ind. - & Org. - \\
\hline & \multicolumn{2}{|c|}{$\begin{array}{l}\text { Better order in handling } \\
\text { information. }\end{array}$} & \multicolumn{2}{|c|}{$\begin{array}{l}\text { High threshold for use } \\
\text { in small projects. }\end{array}$} & \multicolumn{2}{|c|}{$\begin{array}{l}\text { Different structures of } \\
\text { information - inhibiting. }\end{array}$} & \multicolumn{2}{|c|}{$\begin{array}{l}\text { Cultural attitudes that } \\
\text { supports structures - } \\
\text { supporting. }\end{array}$} \\
\hline & Ind. + & Org. + & Ind. N/A & Org. - & Ind. - & Org. - & Ind. + & Org. + \\
\hline & \multicolumn{2}{|c|}{$\begin{array}{l}\text { Common and safe accessibi- } \\
\text { lity of information. }\end{array}$} & \multicolumn{2}{|c|}{$\begin{array}{l}\text { Rules for information } \\
\text { structures are too } \\
\text { inflexible. }\end{array}$} & \multicolumn{2}{|c|}{$\begin{array}{l}\text { Skills and user experience - } \\
\text { mostly supporting. }\end{array}$} & \multicolumn{2}{|c|}{$\begin{array}{l}\text { Different views on the } \\
\text { structures between actors } \\
\text { - inhibiting. }\end{array}$} \\
\hline & Ind. + & Org. + & Ind. - & Org. - & Ind. + & Org. + & Ind. - & Org. - \\
\hline & \multicolumn{2}{|c|}{ Improved communications. } & & & & & & \\
\hline & Ind. + & Org. + & & & & & & \\
\hline \multirow[t]{8}{*}{ EDI } & \multicolumn{2}{|c|}{ Improved invoice process. } & \multicolumn{2}{|c|}{$\begin{array}{l}\text { Other actors' dedica- } \\
\text { tion (suppliers and } \\
\text { customers). }\end{array}$} & \multicolumn{2}{|c|}{$\begin{array}{l}\text { Time and resources to } \\
\text { pursue the matter - inhibi- } \\
\text { ting. }\end{array}$} & \multicolumn{2}{|c|}{$\begin{array}{l}\text { Slow approach to change } \\
\text { in parts of the sector - } \\
\text { inhibiting. }\end{array}$} \\
\hline & Ind. + & Org. + & Ind. N/A & Org. - & Ind. - & Org. - & Ind. N/A & Org. - \\
\hline & \multicolumn{2}{|c|}{ Lower transaction costs. } & \multicolumn{2}{|c|}{$\begin{array}{l}\text { Initial effort in techno- } \\
\text { logy and process. }\end{array}$} & \multicolumn{2}{|c|}{$\begin{array}{l}\text { Easy to calculate return on } \\
\text { investment - supporting. }\end{array}$} & & \\
\hline & Ind. N/A & Org. + & Ind. - & Org. - & Ind. N/A & Org. + & & \\
\hline & \multicolumn{2}{|c|}{$\begin{array}{l}\text { Improved reporting and de- } \\
\text { cision support. }\end{array}$} & & & \multicolumn{2}{|c|}{$\begin{array}{l}\text { Standards exists, they are } \\
\text { however not uniform. - } \\
\text { mostly supporting. }\end{array}$} & & \\
\hline & Ind. N/A & Org. + & & & Ind. - & Org. + & & \\
\hline & \multicolumn{2}{|c|}{$\begin{array}{l}\text { Long-term contracts and } \\
\text { contract loyalty. }\end{array}$} & & & & & & \\
\hline & Ind. - & Org. + & & & & & & \\
\hline \multirow[t]{10}{*}{ BIM } & \multicolumn{2}{|c|}{$\begin{array}{l}\text { More efficient information } \\
\text { flow within the sub- } \\
\text { processes. }\end{array}$} & $\begin{array}{l}\text { Other acto } \\
\text { ment. }\end{array}$ & commit- & $\begin{array}{l}\text { Compatibil } \\
\text { programs, } \\
\text { dards for tr } \\
\text { inhibiting. }\end{array}$ & $\begin{array}{l}\text { veen } \\
\text { stan- } \\
\text { sion- }\end{array}$ & $\begin{array}{l}\text { Individua } \\
\text { change w } \\
\text { - inhibitil }\end{array}$ & $\begin{array}{l}\text { tia to } \\
\text { f working }\end{array}$ \\
\hline & Ind. + & Org. + & Ind. - & Org. - & Ind. - & Org. - & Ind. $-1+$ & Org. - \\
\hline & $\begin{array}{l}\text { More effici } \\
\text { flow throug } \\
\text { as a whole. }\end{array}$ & $\begin{array}{l}\text { formation } \\
\text { he process }\end{array}$ & $\begin{array}{l}\text { Need for c } \\
\text { approach, } \\
\text { and respon }\end{array}$ & $\begin{array}{l}\text { nge in } \\
\text { ocesses } \\
\text { oilities. }\end{array}$ & $\begin{array}{l}\text { Knowledge } \\
\text { pportive. In } \\
\text { it is missing }\end{array}$ & $\begin{array}{l}\text { - su- } \\
\text { g where }\end{array}$ & $\begin{array}{l}\text { Image aro } \\
\text { supportin }\end{array}$ & $3 \mathrm{IM}-$ \\
\hline & Ind. N/A & Org. $+/ \mathrm{N} / \mathrm{A}$ & Ind. - & Org. - & Ind. + & Org. + & Ind. + & Org. + \\
\hline & & & $\begin{array}{l}\text { Requires g } \\
\text { effort in ec }\end{array}$ & $\begin{array}{l}\text { ater } \\
\text { stages. }\end{array}$ & $\begin{array}{l}\text { Technical i } \\
\text { supporting. }\end{array}$ & lcture - & $\begin{array}{l}\text { Different } \\
\text { views on } \\
\text { BIM - inl }\end{array}$ & $\begin{array}{l}\text { ragmented } \\
\text { efinition of } \\
\text { g. }\end{array}$ \\
\hline & & & Ind. N/A & Org. - & Ind. N/A & Org. - & Ind. -- & Org. - \\
\hline & & & & & $\begin{array}{l}\text { Time and } \mathrm{r} \\
\text { supporting } \\
\text { appointed. }\end{array}$ & & $\begin{array}{l}\text { Missing c } \\
\text { the view c } \\
\text { inhibiting }\end{array}$ & $\begin{array}{l}\text { isus on } \\
\text { cesses - }\end{array}$ \\
\hline & & & & & Ind. + & Org. + & Ind. - & Org. - \\
\hline & & & & & $\begin{array}{l}\text { Processes } \\
\text { supportive } \\
\text { whole. Red } \\
\text { work neede }\end{array}$ & $\begin{array}{l}\text { mically } \\
\text { cess as a } \\
\text { ion of } \\
\text { ibiting. }\end{array}$ & $\begin{array}{l}\text { Sector cul } \\
\text { zed at ind } \\
\text { pany leve } \\
\text { owners - }\end{array}$ & $\begin{array}{l}\text { optimi- } \\
\text { al/com- } \\
\text { orocess } \\
\text { iting. }\end{array}$ \\
\hline & & & & & Ind. + & Org. + & Ind. $-/+$ & Org. - \\
\hline
\end{tabular}




\begin{tabular}{|c|c|c|c|}
\hline & & \multicolumn{2}{|c|}{ Does the organization adopt the Innovation? } \\
\hline \multirow{3}{*}{ 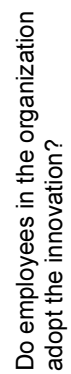 } & & Yes & No \\
\hline & Yes & $\begin{array}{l}\text { Authority-based innovation } \\
\text { adoption }\end{array}$ & Bottom-Up adoption \\
\hline & No & $\begin{array}{l}\text { Adoption but no } \\
\text { deployment }\end{array}$ & Non-adoption \\
\hline
\end{tabular}

Fig. 5. Combinations of individual and organizational decisions for adoption (Gallivan 2001)

\subsection{Factors research}

The research on how innovations are adopted and spread is a research area in which the attitudes and behaviour of potential adopters are studied. Rogers (2003) must be regarded as the leading researcher in what is called Innovation Diffusion Theory (IDT). Other important contributors have included Ajzen (1991), Taylor and Todd (1995) as well as Davis et al. (1989).

A number of models describing factors influencing the use and spread of IT-innovations have been reported in the literature. Tornatzky and Klein (1982) review 75 articles that describe in all 30 different variables influencing the use and spread of IT-innovations, and comment that the number of these variables is continuously increasing and that the variables keep changing names.

Instead of developing further models, Venkatesh et al. (2003) have made a thorough analysis in comparing eight different models and synthesizing an integrated model from these, firstly by making the different concepts and categories used coherent, and secondly by validating the resulting model empirically.

The model, which is called UTAUT - Unified Theory of Acceptance and Use of Technology, is described in Fig. 6. In summary, the three first main groups of factors influence the intention to use a system (behavioural intention), by the expected performance of the use, the expected effort it takes and the social or culture context the user is acting in. The resulting intention together with the fourth main group of factors, Facilitating Conditions - such as technical and organisational infrastructure - influences the real use (use behaviour). Venkatesh et al. (2003) also propose four moderating factors which indirectly influence the "behavioural intention" and "use behaviour" via the four main groups of factors. In this study, the authors have chosen to remove the two moderating factors age and sex. These are purely demographic, non-avoidable factors. If this kind of factors should be included, there are many others as well, such as education, social class, cultural background, etc.

The UTAUT model above (Venkatesh et al. 2003) is focused on the individual level. But since also organizations consist of individuals making decisions based on for them relevant factors the model can also be said to have some relevance in organizations but on different levels in parallel and with different possible outcomes. In general terms all the factors of the model are relevant both for a decision maker on the highest level and the individual who is expected to take into use the innovation, although the variables can have different effects and even conflicting results between the levels. An innovation which supports the company's processes and which improves its profitability need not be perceived as supporting by the individuals who have to apply it. Likewise an innovation which is positively experienced on the individual level can be of limited benefit for the organization if for instance the " $\mathrm{Fa}$ cilitating Conditions" are missing or the "Effort Expectancy" on the level of the organization is too big.

\subsection{Process research}

After a decision has been taken to take an innovation into use, an implementation process starts within the corresponding organisational unit (where the decision was taken). The objective of this process is that the innovation is used to its full potential and that the use becomes routine and a part of everyday activities.

Rogers (2003) divides the innovation process of an organization into totally five steps split into the two major phases called initiation (which leads to the decision) and implementation (which leads to use). Cooper and

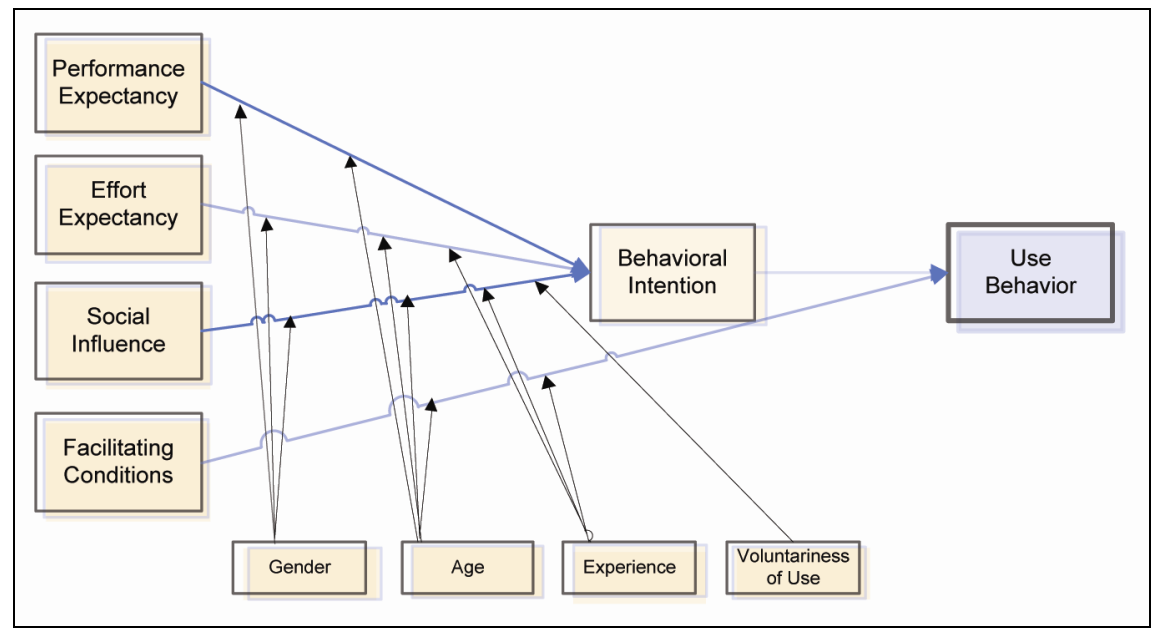

Fig. 6. The unified theory of acceptance and use of technology (UTAUT) model (Venkatesh et al. 2003) 


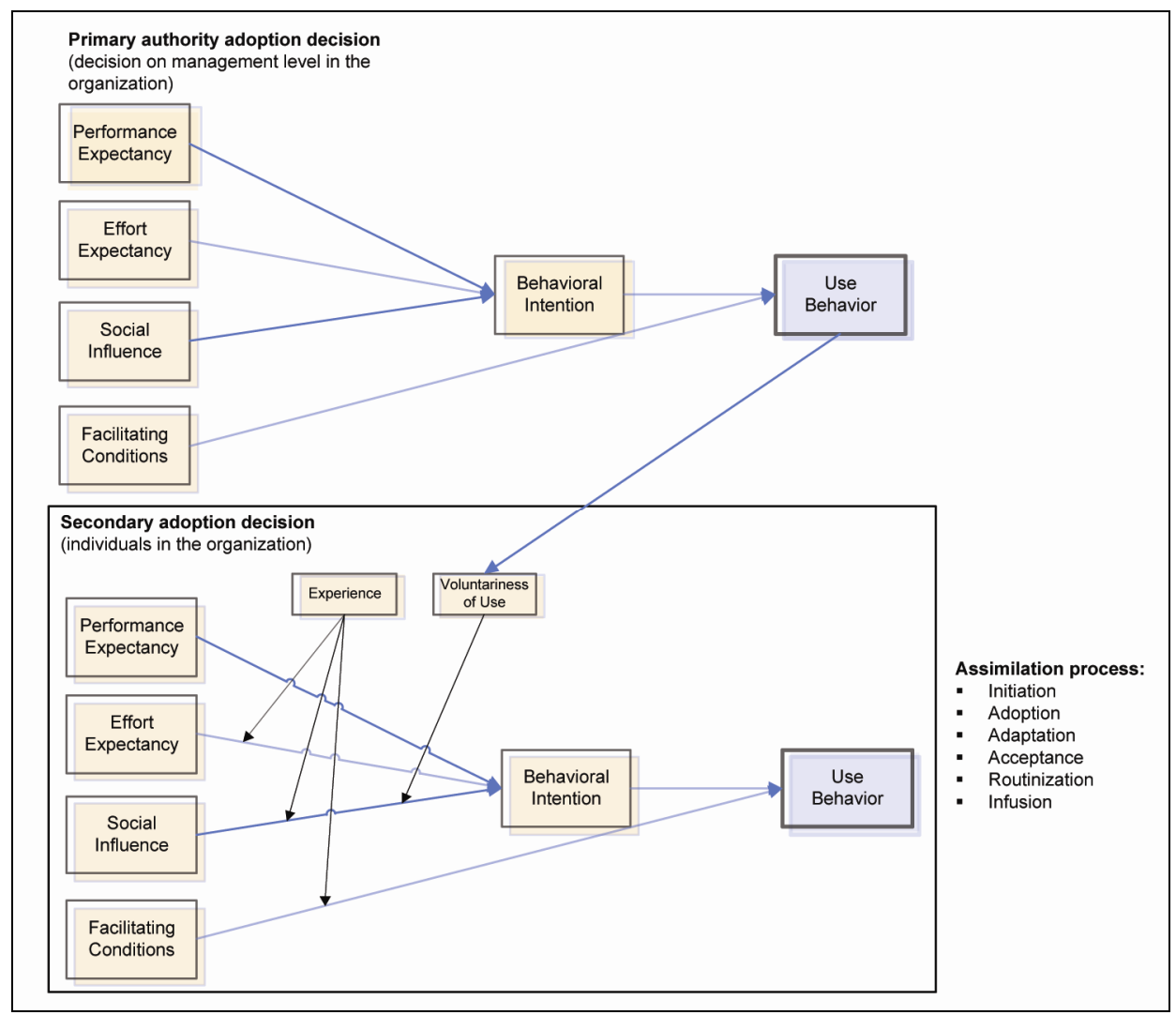

Fig. 7. Proposal for a combination of UTAUT (Venkatesh et al. 2003), Gallivan's two-step model (Gallivan 2001) and the stage model for implementation and assimilation (Samuelson 2008)

Zmud (1990) propose a slightly different structure of the process, including the following six steps:

- Initiation;

- Adoption;

- Adaptation;

- Acceptance;

- Routinization;

- Infusion.

The concepts in these two models resemble each other and emphasize that the use of the innovation should be routine in the organization before the implementation can be regarded as successful.

Gallivan (2001) describes in a two-stage model how the implementation in organizations normally consists of primary decisions on the organizational level and secondary on the individual level. The decisions must then be followed by an implementation process in order to achieve a successful implementation inside the organization, which Gallivan (2001) describes based on the framework of Cooper and Zmud (1990).

\subsection{Theoretical framework}

The analytical framework of the study is based on a combination of the following:

- Levels of decision from the first interview study political research;

- The four field model of individuals and organizations (Gallivan 2001) - political research;
- The UTAUT model (Venkatesh et al. 2003) factors research;

- The two-stage model of individuals and organizations (Gallivan 2001) - factors and process research;

- The process stage model by Cooper and Zmud (1990) - process research.

A proposal for a combination of the static factors of the UTAUT model and the two stage model of Gallivan (2001) (including the process stage model) is described in Fig. 7. The figure describes a decision in two stages where the variables in the UTAUT-model influence both the decision of management and of the individuals. The integration between the levels is provided by the degree of voluntariness that the decision of the management inflicts on the individuals. The UTAUT model can be said to form the first two stages in the implementation process (Initiation and Adoption). The ensuing later stages must then be handled to obtain a broad implementation in the organization (Adaptation, Acceptance, Routinization and Infusion). Two main scenarios can be described based on the figure. In the first (top-down) the primary decision is done on the organizational management level and this influences a secondary decision made by each individual. The management then drives the implementation through the later stages of the process. In another scenario (bottom-up) no decision is made on the organizational management level, but each individual makes an individual and voluntary adoption decision, in this case not influenced by management. The implemen- 
tation process, which lies outside the individual field in the diagram, does not come about before management becomes involved. There is in this case a risk that the process stops with a few users. However, when the management level becomes aware of the implementations that have occurred among employees at the individual level (bottom up) they can choose to manage the implementation from the organizational level in a top-down scenario.

The interview study was made in two parts. The first handled the factors that affected the decisions for adoption of the focus areas, using the UTAUT model to code the answers in the different categories, and the levels where the decisions initially were taken. The model has not been validated statistically, since the purpose of the study was not this, but rather to use the model to sort and categorize the various factors that emerged in the interviews, with large elements of grounded theory in the method.

The second part handled the implementation process, using the stage model by Cooper and Zmud (1990), in order to increase the understanding of what the process has looked like for each of the areas and also to study how far the adoption de facto has progressed in the companies which have reported use of the focus technologies. By studying both the decision- and implementation processes the totality of the innovation process will hopefully be better understood.

\section{Results and discussion}

The results from the interview study are described from the viewpoint of the two parts of the analytical framework where the first focuses on the decision. The factors which influence the decision and the level at which the decisions are made are noted. The second part consists of the implementation process in itself and here the real outcomes are compared with the theoretical stages in the implementation process.

\subsection{Factors and levels of decision-making}

\subsubsection{EDM}

The case companies shared the same view of EDM implementation in projects. All are in agreement that the decisions to use this technology are taken in the individual projects. The consultants say that the clients' requirements are a driving force, and in those companies that act as client organisations the wishes of the individual project leaders are what matters most. Sometimes there are preexisting agreements with software providers, which internally or externally push towards using a certain EDMsystem, but usually there are no explicit requirements on the company level, and hence the decision to use EDM is made in the projects. It is also clear from the interviews that the benefits accrue in the projects.

There are some indications that the individual project participants do not have such great personal benefits of EDM, although the contrary is also claimed. But everybody realizes the benefit for the project as a whole, and that structure is needed in information sharing and communication. Many of the companies see conflicts between internally stored documents and project-EDM, which supports the conclusion that the individual company does not get benefits from project specific EDM in its business processes.

\subsection{2. $E D I$}

EDI investments are decided by the individual companies, in some cases with a certain amount of pressure from a client, regarding faster implementation. None of the interviewed experts have, however, quoted client pressure as a main reason for their own investment. Instead all the companies who use EDI have done their own analysis in which the benefits/savings have been bigger than the costs. In EDI there is more dependence on the investments of other companies than in EDM, where there are hardly any economic or technical thresholds for starting to use the technology. Despite this the investment decisions of others has not significantly influenced the decisions of the case companies. Nevertheless the company experts regard the actions of others as important in order for the technology to spread further. Of the three focus areas EDI is the one in which it is easiest to carry out cost-benefit analyses and to clearly see the advantages for the individual company in terms of more efficient processes and of lower transaction costs. Of the interviewed companies, the contractors are the ones who have utilised EDI most, and where EDI also seems to affect the actual processes in the projects.

The business models of the big contractors include major material flows in which good control over procurement, deliveries and prices is a key determinant of the achieved profit rate. The benefit definitely arises in projects, but it is on the company level that the decisions are made and where the big revenues also occur. An individual project can claim that it optimizes its profit using conventional methods, but it is through big volumes, long term agreements and standardized procedures that the profit is optimised on the company level. For this reason the technology adoption decisions of the contractors have a higher degree of authority decision than among the other companies. It is clear from the interviews that for EDI the decisions are made, and that the benefits occur, on the company level.

\subsection{3. $B I M$}

As indicated earlier BIM is the area which is hardest to describe in a simple way; partly because BIM as a concept is broad, partly because the concept has different meanings for different actors. This is also reflected in the analysis of the interviews where several pictures emerge. There are nevertheless some common denominators. Among both architects and technical consultants, as well as in the case of one of the material producers, the first initiatives have come bottom-up and have emerged based on a clear benefit for the individual in his professional role. After that the companies have formed different types of decisions, higher up in the management hierarchy, to develop BIM further, either through concrete projects or via policy statements. 
Among the interviewed contractors and the building client organization this is not as clear. It should be noted that the client organization included in the cases had not yet implemented BIM, but had started to work with the issue. One of the contractors showed a similar reasoning as the consultants, in that there had been earlier work in different parts of the company to coordinate information, and these efforts had now been assembled by top management under the umbrella of the BIM concept. Otherwise the interviews seem to indicate that BIM efforts to a larger extent are initiated top-down among contractors and clients, than among consultants.

Authority decisions concerning BIM are not discernible on the company level. Among consultants the development is characterized by long term intentions to broaden the usage and to encourage individuals to change their way of working. Among contractors and building clients the development is done in pilot projects and with focused efforts. There are some requirements on BIM use in projects, but these are perceived as unclear by the consultants. This fuzziness could be due to insufficient knowledge about the technology and to uncertainty about which concrete benefits could be achieved. Likewise there is critique going in the other direction, that there is a lack of model based templates and that BIM models are difficult to produce despite client requirements. Thus it seems not uncommon that consultants produce their own models for each phase and fail to reuse the information available in the existing format.

\subsubsection{Summary}

Table 3 summarizes the influencing variables which have become visible during the interviews and sorts them under the four headings in the UTAUT model. Variables listed under "Performance Expectancy" are supporting or encouraging factors for decisions to adopt or implement, and those under "Effort Expectancy" are inhibiting factors and imply some form of effort for the implementation. "Facilitating Conditions" and "Social Influence" are either supporting or inhibiting to implementation, which has been indicated for each factor in the table, both in text, and with a plus $(+)$ for supporting or a minus $(-)$ for inhibiting.

Since the factors may cause different effects on the various implementation levels as discussed earlier, this has been noted for each factor for the individual and organization level respectively. The organization level may apply to either a company or a project. N/A indicates that the factor does not affect the level in question. In some cases, there are combinations in which various organizations or individuals may experience the factor in different ways. An example of this is the Performance Expectancy factor for BIM "More efficient information flow throughout the process as a whole", which is supporting for the client organization, but in practice, N/A for the individual companies in the process.

The conclusions about on which level the initial decision and then the implementation takes place, can be discussed with Fig. 5 as a basis. The figure includes the individual and the organisational level, where the organi- sation consists of either of the company or the project as stated earlier. Each technology starts with an initial decision in some field in the figure and is then moving when the assimilation process takes place. The management of the project organisation decides on the use of EDM and the project workers follow this decision, which is an authority decision. EDM is therefore directly placed in the upper left field in Fig. 5.

The company management decides on the use of EDI and the adoption process starts with building the technical and work flow infrastructures. In the early initiation and adoption phase, EDI is consequently placed in the lower left field where the organisation (company) has decided, but not yet the employees or the business partners. The implementation then takes place in succession via consensus or authority decisions in client or subcontractor relationships, and via authority decisions internally in the company and in the projects. It could thus be said that the decision moves from the lower left field to the upper left in Fig. 5.

The use of BIM is initially mainly decided on by individuals with a high level of knowledge via pilot projects and initiatives of their own, i.e. it starts in the upper right field in Fig. 5. The project and company management, which realise the potential benefits, further pursue the matter but with a low degree of authority. BIM implementation therefore initially takes place "bottom-up" and then moves towards the upper left field, towards decisions on the organisational levels.

Another conclusion to be drawn from the result above concerns the project as a level for decision. As stated earlier in the text, the project can be regarded as an organization, but also as an inter-organizational system. This is made even clearer when studying the focus areas above. The project works as an organization in the EDM case, with well-defined decision paths and hierarchies, where the project management is able to make demands on the participant, as long as the demands are not in conflict with the IT-platforms, processes and culture in the companies of the participants. For BIM on the other hand, the project becomes an inter-organizational system. A single project or its management cannot decide that the hired companies shall use a specific IT-platform for creating and using model based information, if the platform doesn't exist in the companies. To decide to use these platforms are long-term strategic decisions for each company and demands both investments in licenses and in education and training for the employees. Instead, the project is dependent of the overall development in the sector regarding IT tools, but can require the use of them if they exist among the companies. For these kinds of innovations, the project will become part of the interorganizational social system that handles the cooperation between companies in the sector.

\subsection{Implementation}

The model chosen (Cooper, Zmud 1990; Gallivan 2001) for comparing the implementation processes in the focus areas consists of six steps: Initiation, Adoption, Adaption, Acceptance, Routinization and Infusion. Below, the im- 
plementation processes for the focus areas in the interviewed companies are compared for each step. After that an evaluation is made of how far these technology areas have been implemented in the companies and in the sector as a whole, partly based on the interviews, partly on the quantitative results of the 2007 IT-barometer.

\subsubsection{Initiation and adoption}

In all three areas the companies have gone through the initiation phase and have to some extent identified what they want to achieve by development efforts in that area, and have made some sort of decision. In the case of EDM the initiation takes place in individual projects in contrast to the two other areas in which it takes place mainly on the company level. Initiation and decisions about BIM are made on the project level, but according to the respondents in a too small scale and with too little knowledge. The potential to create an equally strong influence on BIM (as for EDM) thus exists, but it is doubtful if the sector is yet ripe for this.

The decisions to allocate resources and activities for the implementation have, to the extent such decisions have been needed, been made concerning EDM and EDI, but only in a few cases for BIM.

It is a paradox that BIM which is perceived as the most difficult and most complex area of development, and at the same time as the area promising the greatest benefits, has received less strategic resources from the companies than the more simple innovations.

\subsubsection{Adaptation and acceptance}

For EDM and EDI some adaptations of organisation and processes have been made. The introduction of EDM has meant that the logic in information flow has changed from push to pull. EDI has had consequences for the administrative work-flow and for the handling of reports, and has for contractors meant new ways to plan and carry out purchases. EDM shows least changes whereas EDI has required more substantial adaptation. For BIM the respondents envisage big changes both in process and organisation, but few of them have yet occurred. New roles in the form of BIM-experts will be created, but otherwise BIM is still used in the same process as before.

The availability and acceptance follow the same pattern for each of the areas. EDM is available for all and is also largely accepted as a tool. The same goes for EDI as an administrative work-flow tool, whereas its acceptance is lower among those individuals who need to find out information about materials and make orders. The interviews also imply that those who have implemented BIM have created availability for parts of the organisations, but not for all. The number of individuals who have accepted the technology and have taken it into use is also much lower. Among the most active companies there are however activities such as seminars, training and campaigns to promote BIM.

\subsubsection{Routinization and infusion}

EDM has achieved routinized use in the sector. It is no longer perceived as something new or special but belongs to the routine in many projects, where project specific standards are developed as needed. EDI has become routine in the administrative work-flow in companies, but not yet in the first phases of the e-commerce process, orders and orders on call. BIM is on the contrary not in routine use, this the respondents agree on. One of the companies which had made the best progress in this focus area has developed routines for its internal use, but these have not yet been implemented more broadly throughout the whole project workflow. Neither are there any routines for cooperation in projects within the sector but these are formed project by project.

There is no clear indication of a migration to new and broader implementation areas in any of the focus areas. For EDI some examples were given of how the structured information in the economic work-flow could be used for value-adding analyses, which now have become more in focus than originally intended. EDM is described as a "ready technique" where the expectations have rather been lowered to a realistic level.

Many respondents see a paradigm shift in an envisaged merger between EDM and BIM, put place this far into the future. BIM has not yet even delivered the benefits in the visions. On the contrary the use of pragmatic direct bilateral data transfer between applications can be said to have lowered the expectations, but has on the same time contributed to the concrete application of the technology in the industry. This change in the vision is an example of a re-invention, (cf: Rogers 2003; Berman, Pauly 1975), where the innovation is adapted to the prevailing conditions and the spread of it is accelerated.

To summarize, the interviews show that EDM is the innovation which most clearly has passed through the stages in the implementation process, from initiation to routine usage. Also in the case of EDI most of the steps have been taken by the interviewed companies, but the development efforts have been more substantial and routine use is not yet so common. Lastly, BIM has not been implemented so systematically and several of the steps in the process are missing. The IT barometer, version 2007, indicates uptake levels of $40 \%$ for EDM, around $20 \%$ for EDI and around $10 \%$ for BIM in the industry. The interviews also paint a picture where EDM is the most mature technology, followed by EDI with BIM being the least developed. At the same time the interviews also clearly indicate that the degree of complexity and the need to change working practices are in the reverse order, with BIM being the without doubt most difficult technology.

\section{Conclusions and final comments}

The main conclusions of the study can be divided into two parts. Firstly, conclusions about the level where the initial decisions are made and which factors that influence this. Secondly, conclusions about the actual implementation of the systems, and how well the steps in the 
theoretical process are followed, with connection to influencing factors.

The initial decision for implementation is made at the project level for EDM, and on a company level for EDI. It is also at these levels respectively that the benefits or the "performance expectancy" occurs. The decision level is thus linked to the benefit in a logical manner. For $\mathrm{BIM}$, this connection is more complex. The original vision of BIM was about the value of an unbroken information chain within the construction process as well as throughout the construction and facility management processes in a life cycle perspective. So far, the initial decisions for BIM have mostly been taken at the individual level, or sometimes at the company level, but for single actors in the industry. The decisions have been taken only where the benefits are limited in a sub process in order to streamline this existing process. Decisions need to be taken where the benefits are expected to occur, and that management level may also require changes to existing processes, which is required to utilize BIM to its fullest potential. Regarding BIM implementation the project-level should be considered as an interorganizational system, which needs a strong decision maker. The implementation is hampered today by the lack of strong process owners and lack of standardization.

The actual implementation can be considered in width as well as in depth, where the width is the spread of the use in companies and projects, and where the depth is about how developed and mature this use has become. EDM is more advanced in both prevalence and degree of maturity, except for the infusion phase, where no specific further development has occurred. EDI is not as widespread, but has matured well and achieves many of the later stages of the implementation process. BIM is the least widespread technology, and even where it is used, it is in fact only the first two or three steps in the implementation process that have been covered.

Thus, both prevalence and maturity in implementation decreases with an increased complexity of systems. The less complex systems are easier and quicker to implement than more complex ones. The areas with more complex information structures have also gone through fewer steps in the implementation process, and companies have not gone through them as thoroughly. This may seem a paradox when the need to handle the issues is greater when the complexity is higher. The need for, or rather the lack of, information standards is also more and more evident with the complexity of the system. One explanation for why the management in the companies act less vigorously in implementing the more complex systems may be that information exchange between different actors is difficult to handle for the individual firm. When the information increases in complexity, the implementation requires more expertise and more coordination between companies, which is hard to manage in the construction sector with its structure of temporary project-based organizations.

The findings of the study hopefully contribute to the research area by combining general IT adoption theory with the subject of IT in construction, and by presenting results regarding adoption of three important IT tools. The study has also suggested three different levels for implementation: individual, organizational and inter organizational, which has been shown to be important for the implementation strategy. The results can also be used by companies in the industry to better understand how to handle implementation of different kinds of system at different levels.

The data collection for this study was made in Sweden. There are, however, reasons to believe that most of the conclusions can be generalized to other countries, since the construction industry stakeholders and the organisation of construction projects are quite similar in different countries. External factors such as government laws, regulations, industry maturity etc. which can be different, would not be likely to affect the main factors considered in this study. But this has to be investigated, and can be subject for further research.

\section{Acknowledgements}

This article is based on earlier unpublished parts of the $\mathrm{PhD}$ thesis of Olle Samuelson, which was successfully defended at the Hanken School of Economics in September 2010 (Samuelson 2010). The quantitative parts of the thesis work have been reported on earlier in journal articles in English (Samuelson 2002, 2008) Bo-Christer Björk acted as supervisor of the thesis and contributed to this article. The valuable comments of Mikael Laakso are acknowledged. The study would not have been possible to carry out without the financial support of the Sven Tyréns foundation.

\section{References}

Ajzen, I. 1991. The theory of planned behaviour, Organizational Behavior and Human Decision Processes 50(2): 179211. http://dx.doi.org/10.1016/0749-5978(91)90020-T

Amor, R.; Betts, M.; Coetzee, G.; Sexton, M. 2002. Information technology for construction: recent work and future directions, ITcon 7: 245-258. Available from Internet: http://www.itcon.org/2002/16

Azhar, S.; Hein, M.; Sketo, B. 2008. Building Information Modelling (BIM): benefits, risks and challenges, in Proceedings of the $44^{\text {th }}$ ASC Annual Conference (on CD ROM), April 2-5, 2008, Auburn, Alabama.

Berman, P.; Pauly, E. W. 1975. Federal programs supporting educational change. Vol. 2: Factors affecting change agent projects. Report. Rand Corporation, Santa Monica, USA.

Björk, B.-C. 2006. Electronic document management in temporary project organisations - construction industry experiences, Online Information Review 30(6): 644-655. http://dx.doi.org/10.1108/14684520610716144

Björk, B.-C.; Laakso, M. 2010. CAD standardization in construction - a process view, Special issue on BIM standardization, Automation in Construction 19(4): 398-406. http://dx.doi.org/10.1016/j.autcon.2009.11.010

Blayse, A. M.; Manley, K. 2004. Key influences on construction innovation, Construction Innovation 4(3): 143-154. http://dx.doi.org/10.1191/1471417504ci073oa 
Building Smart. 2010. Model - Industry Foundation Classes (IFC) [online], [cited 20 October 2010]. Available from Internet: http://www.buildingsmart.com/bim

Cooper, R. B.; Zmud, R. W. 1990. Information technology implementation research: a technological diffusion approach, Management Science 36 (2): 123-139. http://dx.doi.org/10.1287/mnsc.36.2.123

Davis, F. D.; Bagozzi, R. P.; Warshaw, P. R. 1989. User acceptance of computer technology: a comparison of two theoretical models, Management Science 35(8): 9821003. http://dx.doi.org/10.1287/mnsc.35.8.982

Dubois, A.; Gadde, L.-E. 2002. The construction industry as a loosely coupled system: implications for productivity and innovation, Construction Management and Economics 20: 621-631. http://dx.doi.org/10.1080/01446190210163543

Eastman, C.; Teicholz, P.; Sacks, R.; Liston, K. 2008. BIM handbook, a guide to building information modelling for owners, managers, designers, engineers and contractors. 3rd ed. Hoboken, New Jersey: John Wiley \& Sons, Inc.

Gallivan, M. J. 2001. Organizational adoption and assimilation of complex technological innovations: development and application of a new framework, The DATA BASE for Advances in Information Systems 32(3): 51-85. http://dx.doi.org/10.1145/506724.506729

Gambatese, J. A.; Hallowell, M. 2011. Factors that influence the development and diffusion of technical innovations in the construction industry, Construction Management and Economics 29(5): 507-517. http://dx.doi.org/10.1080/01446193.2011.570355

Gann, D. M.; Salter, A. J. 2000. Innovation in project-based, service-enhanced firms: the construction of complex products and systems, Research Policy 29(7-8): 955-972. http://dx.doi.org/10.1016/S0048-7333(00)00114-1

Hill, N. C.; Ferguson, D. M. 1998. Electronic data interchange: a definition and perspective, EDI forum, The Journal of Electronic Data Interchange 1(1): 5-12.

Hjelt, M.; Björk, B.-C. 2007. End-user attitudes towards EDM use in construction project work: case study, ASCE Journal of Computing in Civil Engineering 21(4): 289-300. http://dx.doi.org/10.1061/(ASCE)0887-3801(2007)21:4 (289)

Howard, R.; Björk, B.-C. 2008. Building information modelling - experts' views on standardisation and industry deployment, Advanced Engineering Informatics 22(2): 271280. http://dx.doi.org/10.1016/j.aei.2007.03.001

Kiviniemi, A. 2006. Ten years of IFC development. Why are we not there yet?, CIB conference presentation, Toronto.

Koskela, L.; Dave, B. 2008. Process and IT, Construction Innovation 8(4): 244-249. http://dx.doi.org/10.1108/14714170810912635

Kunz, J.; Fischer, M. 2009. Virtual design and construction: themes, case studies and implementation suggestions. CIFE Working Paper \#097, Version 10. Center for Integrated Facility Engineering, Stanford University, Stanford, USA.

Laage-Hellman, J.; Gadde, L.-E. 1996. Information technology and the efficiency of materials supply: the implementation of EDI in the Swedish construction industry, European Journal of Purchasing \& Supply Management 2(4): 221228. http://dx.doi.org/10.1016/S0969-7012(96)00018-4

Löwnertz, K. 1998. Change and exchange - electronic document management in building design: Licentiate Thesis, Department of Construction Management and Organisation, Royal Institute of Technology, Stockholm, Sweden.
Muehlen, M.; Nickerson, J. V.; Swenson, K. D. 2005. Developing web services choreography standards - the case of REST vs. SOAP, Decision Support Systems 40(1): 9-29. http://dx.doi.org/10.1016/j.dss.2004.04.008

Nitithamyong, P.; Skibniewski, M. 2004. Web-based construction project management systems: how to make them successful?, Automation in Construction 13(4): 491-506. http://dx.doi.org/10.1016/j.autcon.2004.02.003

O'Brien, M. J.; Al-Soufi, A. 1993. Electronic data interchange and the structure of the UK construction industry, Construction Management and Economics 11(6): 443-453. http://dx.doi.org/10.1080/01446199300000050

O'Brien, W. 2000. Implementation issues in project web-sites: a practitioner's viewpoint, ASCE Journal of Management in Engineering 16(3): 34-39. http://dx.doi.org/10.1061/ (ASCE)0742-597X(2000)16:3(34)

Olofsson, T.; Lee, G.; Eastman, C. 2008 Editorial - case studies of BIM in use, ITcon (Special issue. Case studies of BIM use) 13: 244-245. Available from Internet: http://www.itcon.org/2008/17

Peansupap, V.; Walker, D. 2005. Exploratory factors influencing information and communication technology diffusion and adoption within Australian construction organizations: a micro analysis, Construction Innovation 5(3): 135-157. http://dx.doi.org/10.1191/1471417505ci095oa

Ramamurthy, K.; Premkumar, G.; Crum, M. R. 1999. Organizational and interorganizational determinants of EDI diffusion and organizational performance: a causal model, Journal of Organizational Computing and Electronic Commerce 9(4): 235-285. http://dx.doi.org/10.1207/S153277440904_2

Rogers, E. M. 2003. Diffusion of innovations. $5^{\text {th }}$ ed. New York: Free Press. 576 p.

Samuelson, O. 2002. IT-barometer 2000 - The use of IT in the Nordic construction industry, ITcon 7: 1-26. Available from Internet: http://www.itcon.org/2002/1.

Samuelson, O. 2008. The IT-barometer - a decade's development of IT use in the Swedish construction sector, ITcon 13: 1-19. Available from Internet: http://www.itcon.org/2008/1.

Samuelson, O. 2010. IT-innovationer $i$ svenska bygg-och fastighetssektorn - En studie av förekomst och utveckling av IT under ett decennium (IT innovations in the Swedish construction and facility management sector. - A study of occurrence and development in a decade): $\mathrm{PhD}$ Thesis, Department of management and organisation, Hanken, Helsinki, Finland. Available from Internet: http://hdl.handle.net/10227/662

Slaughter, E. S. 1998. Models of construction innovation, Journal of Construction Engineering and Management 124(3): 226-231. http://dx.doi.org/10.1061/(ASCE)0733-9364 (1998)124:3(226)

Slaughter, E. S. 2000. Implementation of construction innovations, Building Research and Information 28(1): 2-17. http://dx.doi.org/10.1080/096132100369055

Stewart, R. A.; Mohamed, S.; Marosszeky, M. 2004. An empirical investigation into the link between information technology implementation barriers and coping strategies in the Australian construction industry, Construction Innovation 4(3): 155-171. http://dx.doi.org/10.1191/1471417504ci074oa

Suermann, P. C.; Issa, R. A. 2007. Evaluating the impact of Building Information Modeling (BIM) on Construction, in 7th International Conference on Construction Applica- 
tions of Virtual Reality, October 22-23, 2007, University Park, Pennsylvania, USA.

Sulankivi, K.; Lakka, A.; Luedke, M. 2002. Project management in the concurrent engineering environment [online]. VTT Publications, Technical Research Centre of Finland. Available from Internet: http://www.vtt.fi/rte/cmp/projects/proce/indexe.html

Tarandi, V. 1998. Neutral intelligent CAD communication information exchange in construction based upon a minimal schema: $\mathrm{PhD}$ Thesis, Department of construction management and organisation, KTH, Stockholm, Sweden.

Taylor, S.; Todd, P. A. 1995. Understanding information technology usage: a test of competing models, Information Systems Research 6(2): 144-176. http://dx.doi.org/10.1287/isre.6.2.144

Thomas, S. R. 1999. Impacts of design/information technology on project outcomes. Report NIST GCRpp. 99-786, National Institute of Standards and Technology, Gaithersburg, Md., USA
Thorpe, T.; Mead, S. 2001. Project-specific web sites: friend or foe?, Journal of Construction Engineering and Management 127(5): 406-413. http://dx.doi.org/10.1061/(ASCE) 0733-9364(2001)127:5(406)

Tornatzky, L. G.; Klein, K. J. 1982. Innovation characteristics and innovation adoption-implementation: a meta-analysis of findings, IEEE Transactions on Engineering Management 29(1): 28-43. http://dx.doi.org/10.1109/TEM.1982.6447463

Venkatesh, V.; Morris, M. G.; Davis, G. B.; Davis, F. D. 2003. User acceptance of information technology: toward a unified view, MS Quarterly 27(3): 425-478.

Yin, R. K. 2009. Case study research, design and methods. $4^{\text {th }}$ ed. California: SAGE Publications Inc. 219 p.

Olle SAMUELSON has recently been employed as research strategist at the trade organization IQS in Sweden (Association for Innovation and Quality in the construction sector). He has a background as IT Manager and IT Strategist at the consultant company Tyréns. He has more than 20 years' experience of the construction sector and has been a part time researcher for more than 10 years. His research is focused on IT adoption in construction and he has developed a survey tool - the IT Barometer - for measuring the use of IT in the construction and real estate sector, which has been used, more or less, in eleven different countries during a period of more than 10 years.

Bo-Christer BJÖRK is currently a Professor of Information Systems Science at the Hanken School of Economics, Helsinki, Finland. Prior to that, he was a Professor of IT in construction at the Royal Institute of Technology, Stockholm, Sweden. He is a pioneer of Building Information Modeling Research and has published over 40 peer reviewed journal articles. He is the founder of the Journal of Information Technology in Construction, the first Open Access scholarly journal in Civil Engineering, and was its Editor-In-Chief for fifteen years. He is also a member of editorial board in five other scientific journals and is also currently conducting research concerning the changes in scholarly communication due to the Internet. In 2010 he received the CIB Commission recognition award for his contributions over the past twenty years to developing the field of Construction IT research. 